Research Report No. 10/2008

\title{
Book Review - Should it Have Been Called Republic.Com 1.5? : Reviewing Cass Sunstein's 'Republic.com 2.0' (2007)
}

Peter Jenkins

Follow this and additional works at: http:/ / digitalcommons.osgoode.yorku.ca/clpe

\section{Recommended Citation}

Jenkins, Peter, "Book Review - Should it Have Been Called Republic.Com 1.5? : Reviewing Cass Sunstein's 'Republic.com 2.0' (2007)"

(2008). Comparative Research in Law \& Political Economy. Research Paper No. 10/2008.

http://digitalcommons.osgoode.yorku.ca/clpe/184 


\section{Comparative Research in Law \& Political Economy}

\section{Peter S. J enkins}

Book Review - Should It Have Been Called Republic.com 1.5? Reviewing Cass Sunstein's Republic. com 2.0 (2007)

EDTORS: Peer Zumbansen (Osgoode Hall Law School, Toronto, Director, Comparative Research in Law and Political Economy, York University), John W. Cioffi (University of California at Riverside), Lindsay Krauss (Osgoode Hall Law School, Toronto, Production Editor) 

CLPE Research Paper 10/2008

Vol. 04 No. 02 (2008)

Peter S. Jenkins

\section{SHOULD It HAVE BEEN CALLED REPUBLIC.COM 1.5? REVIEWING CASS SUNSTEIN's REPUBLIC.COM 2.0 (2007)}

Abstract: Sunstein's argument in the original 2001 Republic.com and in this new 2007 version is that democracy requires a range of common experiences (social glue) and unanticipated exposure to diverse points of view, but that the Internet fails society on both counts. Sunstein believes that the Internet tends to create social fragmentation by encouraging individuals to sort themselves into deliberative enclaves of like-minded people and assisting them to filter out unwanted, opposing opinions. Republic.com 2.0 is much less than it could have been had the author cited opposing points of view more frequently, not been so US-centric, and considered recent uses of the Internet to enhance democracy, such as voter mobilization and politician voting record sites. The book would also have benefited considerably from a discussion of virtual worlds, such as Second Life. Sunstein should be given credit, however, for withdrawing the misguided policy proposal presented in the original 2001 Republic.com for legislation requiring cross-links between web sites of opposing viewpoints.

Keywords: 9/11, cross-linking, web 2.0, deliberative democracy, voter mobilization, political transparency, transaction costs, free speech, information aggregation, perfect filtering, virtual worlds.

JEL classification: D23, K39

\section{Author Contact:}

Peter S. Jenkins

Ph.D. Candidate, Osgoode Hall Law School, York University

4700 Keele Street, Toronto, ON M3J 1P3

Email: peterjenkins@osgoode.yorku.ca 


\title{
Book ReView - Should It Have Been Called REPUBLIC.COM 1.5? REVIEWING CASS SUNSTEIN'S REPUBLIC.COM 2.0 (2007)
}

\author{
Peter S. Jenkins*
}

[Cass R. Sunstein, Republic.com 2.0, Princeton University Press (2007) , ISBN-13: 978-0-691-13356-0, pp. 251, \$24.95]

The original version of this book, Republic.com, was published in the spring of 2001. I read it very soon after 9/11 and was immediately drawn to the original book's clear and cogent style. Sunstein's argument is that democracy requires a range of common experiences (social glue) and unanticipated exposure to diverse points of view, but that the Internet fails society on both counts. Sunstein believes that the Internet tends to create social fragmentation by encouraging individuals to sort themselves into deliberative enclaves of like-minded people and assisting them to filter out unwanted, opposing opinions. Sunstein's original work was instrumental in propelling me into the field of Internet and virtual world research and, in 2002, I applied Sunstein's argument to the field of electronic labor picketing ${ }^{1}$. My research along these lines, conducted in the aftermath of 9/11, deepened my original conviction that Sunstein was right, at least in the context of labor disputes, although I disagreed with his recommendation for legislation requiring cross-links between opposing parties' web sites. I discovered that, in 2000, the Service Employees International Union (SEIU) attempted to conduct an electronic picketing campaign against Argenbright Security, the company that provided security for $40 \%$ of US airports, including at Newark and Dulles

\footnotetext{
* Ph.D. candidate at Osgoode Hall Law School, York University. Member of the State Bar of California. Email: peterjenkins@osgoode.yorku.ca

${ }^{1}$ Peter S. Jenkins, Leafleting and Picketing on the "Cydewalk" - Four Models of the Role of the Internet in Labour Disputes, 7 UCLA JOURNAL OF LAW \& TECHNOLOGY (2003), available at: http://ssrn.com/abstract=470682. All websites referenced were last accessed 31 January 2008.
} 
International, from where two of the hijacked planes departed. SEIU was experiencing strong employer resistance in attempting to organize Argenbright staff, who were paid about $\$ 15,000$ per year and received insufficient training. SEIU took out banner ads on Yahoo, which appeared whenever someone entered Argenbright into the Yahoo search engine. SEIU was subsequently forced by Yahoo to drop the ads on the basis that they were contrary to Yahoo's policy². At the same time as this was unfolding, the al Qaeda terrorists were using the Internet to communicate with each other to hone the plans for the 9/11 attacks. This seemed to me to perfectly illustrate Sunstein's point. If Yahoo had allowed the electronic picketing, then the resulting public awareness of the issues may have led to unionization of Argenbright, better trained, better qualified and more committed security staff at US airports, and the prevention of 9/11, thereby quashing the plans hatched by al Qaeda terrorists in their deliberative enclaves on the Internet. However, events of course took a horribly different turn.

Given this background then, it would seem that I should be giving a more enthusiastic reception to Sunstein's Republic.com 2.0. However, although Sunstein is advocating the fostering of norms providing for cross-linking to web sites with differing points of view, there is an astonishing (and rather hypocritical) lack of such cross-referencing in his new book ${ }^{3}$. Following the publication of the original Republic.com, there were numerous articles in scholarly journals ${ }^{4}$ as well as mainstream, national

${ }^{2}$ Labornet Newsline Yahoo! Cancels Banner Ads Placed by SEIU, 18 February 2000, available at: http://www.labornet.org/news/030100/05.html

${ }^{3}$ Sunstein's tendency to avoid referring to many of his critics also extends into omitting the full context of important case law, where that context does not necessarily support his view. For example, in his discussion of the US Supreme Court case which required shopping mall owners to keep their property open for expressive purposes, Pruneyard Shopping Center v. Robbins, 447 U.S. 74 (1980), (SUNSTEIN, 180) he neglects to mention that the decision narrowly ruled on the interaction of the US Constitution and the California State Constitution, i.e. the former only provides for a negative command to Congress not to interfere with freedom of speech, while the latter provides for an affirmative right, and therefore the latter can provide supplementary rights as long as they do not interfere with federal constitutional rights. Hence, approximately half of the states in the US have the opposite result to California.

${ }^{4}$ e.g. Mark S. Nadel, Customized News Services and Extremist Enclaves in Republic.com, 54 Stanford Law Review 831 (2002); Dan Hunter, Phillipic.com, 90 CALIFORNIA LAW 
publications $^{5}$, providing constructive and valuable criticisms of his work. However, very few of these responses are specifically mentioned in his new book. For example, in the summer of 2001, the Boston Review published a discussion of the original Republic.com, featuring critical commentaries by seven well-known scholars in the fields of journalism, communications, media and sociology - Jay Rosen, Simson Garfinkel, Michael Schudson, Ronald N. Jacobs, Shanto Iyengar, Henry Jenkins and Robert McChesney. ${ }^{6}$ However, not one of these pieces is mentioned in Sunstein's new book. I will grant that one of these authors, Shanto Iyengar of Stanford University, has significantly changed his position from his 2001 piece $^{7}$, but most of them, including the influential MIT media scholar, Henry Jenkins, have not. Henry Jenkins (who is not related to me) points out several compelling counter-arguments, including that individuals often tend to be members of several different groups, some with overlapping interests and topics of discussion ${ }^{8}$. This tends to mitigate any homogenizing influences that any one group may have. For example, a person may be a member of a political discussion group, a baseball fan group, a bird-watchers' club and a fans of Harry Potter club. Although these groups have different focuses, there may be overlapping issues of discussion. The Harry Potter fan club may sometimes verge into political discussions which will tend to contain diverse political perspectives, which may be lacking in the political discussion group. Another perceptive point that Henry Jenkins raises ${ }^{9}$ is that individuals often tend to settle in geographic locations according to their political beliefs, e.g. so-called

REVIEW 611 (2002); Anupam Chander, Whose Republic? 69:3 UnIVERSITY OF CHICAGO LAW REVIEW, 1479 (2002);

5 e.g. James Fallows, He's Got Mail, 49 THE NEW YoRK REVIEW OF BOOKS 4 (2002), available at: http://www.nybooks.com/articles/15180.

${ }^{6}$ Is the Internet Good for Democracy? Boston REVIEW (Summer 2001), available at: http://bostonreview.net/ndf.html\#Internet.

${ }^{7}$ Shanto Iyengar and Richard Morin, Red Media, Blue Media, Evidence of Ideological Polarization in Media Use, AnNuAl MeEting of THE InTERnAtional Communication AsSOCIATION (2007)

${ }^{8}$ Henry Jenkins, Challenging the Consensus - A Response to the Daily We, Boston REVIEW (Summer 2001), available at: http://bostonreview.net/BR26.3/jenkins.html.

9 Henry Jenkins, Convergence Culture 238 (2006) 
"red" and "blue" states in the US. As such, fragmentation is not purely the result of the media such as the Internet, but also physical proximity. Furthermore, as Simson Garfinkel ${ }^{10}$ has pointed out, the Internet tends to collapse and transcend geographic distinctions, and makes national news media easier to access, thereby acting as a countervailing balance to fragmented local interests.

Sunstein's critics recognize that the main problems with the democratic process do not arise from fragmentation of public opinion, but rather from voter apathy and low turn-out combined with a lack of readily available information on which to base voter choice, e.g. legislative voting records and political contributions. ${ }^{11}$ However, Sunstein fails to address these two fundamental problems with the democratic process. Web sites such as www.moveon.org have greatly increased civic participation in the democratic process. Statistics from the US Federal Election Commission ${ }^{12}$ show that voter turn-out in the 2004 Presidential election was 55.3\% which is the highest level since 1968. Voter turn-out reached a low in 1996, when it was $49.1 \%$, at a time when the Internet was still in its infancy, and voter cynicism was at an all-time high. Although the Federal Election Commission statistics demonstrate that mid-term Federal elections for Congress have remained consistently low (under 40\%) since 1974, efforts in the area of web-based transparency promoted by scholars and activists such as Larry Lessig of Stanford University have the potential to ameliorate voter apathy and lack of information at the local level. For example, http://www.maplight.org/ links together information on political contributions, voting records and corporate interests of US Congresspersons.

\footnotetext{
${ }^{10}$ Simson Garfinkel, The Mathematics of Growth - A Response to the Daily We, Boston REVIEW (Summer 2001), available at: http://bostonreview.net/BR26.3/garfinkel.html.

${ }^{11}$ Robert W. McChesney, Power to the Producers - A Response to the Daily We, BostoN REVIEW (Summer 2001), available at: http://bostonreview.net/BR26.3/mcchesney.html. McChesney points out, for example, in the 2000 US Presidential election, exit polls showed that the richest 20 percent of Americans accounted for 50 percent of all the voters.

${ }^{12}$ Available at: http://www.infoplease.com/ipa/A0781453.html.
} 
Sunstein quotes the dictum of Justice Brandeis that "Sunlight is the best of disinfectants" 13 in advocating for policies or legislation requiring mainstream broadcast outlets to disclose the type and extent of their public service and public interest activities as a countervailing measure to the alleged fragmentation of opinion caused by the Internet. However, Sunstein does not make any mention of the real root of the problem with democratic debate, i.e. the lack of transparency in the political process itself, and the logical solution, which is to use the Internet as the sunshine to illuminate the records and interests of politicians. Instead, Sunstein dwells excessively on statistics that purport to show the lack of links between web sites or blogs of opposing viewpoints, without even mentioning new trends towards blog aggregation services, which provide a convenient review of the range of opinions on various blogs. ${ }^{14}$ Sunstein's focusing on mandatory disclosure measures to regulate mainstream media outlets and best practices to encourage cross-links between opposing sites is, at best, an ineffectual red herring and probably actually a dangerous diversion from the real problems of voter apathy and lack of transparency in the political process. This presumably deliberate omission is compounded by the irony of the fact that Republic.com 2.0 fails to cite and discuss the opposing points of view on the matter. In fact, the very ease with which one can access and compare these opposing points of view on the Internet, specifically the Boston Review series of comments, speaks to the power of the Internet to expose individuals to alternative points of view.

I will give Sunstein credit that in Republic.com 2.0, he has dropped the proposal for legislation mandating links between sites of opposing viewpoints. In the original Republic.com, Sunstein stated that "If these routes [i.e. voluntary codes of practices] do not work, it would be worthwhile considering content-neutral regulation, designed to ensure more in the way of both links and hyperlinks."15 Sunstein seems to have

\footnotetext{
${ }^{13}$ Sunstein, 197

14 See Mark Glaser, Human and Automated Aggregators Help Make Sense of Blogosphere, ONLINE JOURNALISM REVIEW, ANNENBERG SCHOOL OF JOURNALISM, UNIVERSITY OF SOUTHERN CALIFORNIA (2005), available at: http://www.ojr.org/ojr/stories/050405glaser/

${ }^{15}$ SUNSTEIN, 188
} 
attempted to justify this proposal constitutionally in the original book by adverting to the notion that the scarcity of spectrum argument that originally supported the fairness doctrine could be revived in the context of the Internet, where there is a scarcity of attention ${ }^{16}$. However, in Republic.com 2.0, Sunstein has an unexplained change of opinion, merely saying that "I do not suggest or believe that government should require anything of this kind. Some constitutional questions are hard, but this one is easy: any such amendments would violate the First Amendment." ${ }^{, 17}$ This begs the question of why Sunstein apparently did not grasp the issue the first time around, since there were evidently no material shifts in the constitutional case law in the meantime. In Republic.com 2.0, Sunstein repeats his extensive elaboration of the theme from the original book that freedom of speech is not absolute and only exists through the coercive powers of the state which, for example, prevent an armed thug or a terrorist group from forcing a newspaper to print a certain manifesto. (One wonders why there is no qualifying reference in the book to how the Unabomber Manifesto was published in the New York Times ${ }^{18}$.) In the original book, Sunstein's freedom of speech as a coercive right argument laid the foundation for his ultimate recommendation that government regulation in the form of mandated cross-links should be considered. However, in his new book, where he abandons this recommendation, without any reasoned explanation, his extensive argument concerning the coercive nature of freedom of speech rights is like an enormous foundation on which nothing is built, or a superhighway that leads nowhere. Granted, Sunstein does retain the recommendation from the original book that the government should subsidize deliberative domains, but this is a rather anemic recommendation not requiring extensive constitutional justification. It would be as if Morris Cohen, after his extensive analysis of the coercive nature of property and contract rights ${ }^{19}$, concluded that minimum wage laws would be unconstitutional, but that wage subsidies

${ }^{16}$ See, for example, Robert Bichler, Attention as a scarce resource in an informationbased society, ICT\&S CENTER, UNIVERSITY OF SALZBURG (2005), available at: http://www.mdpi.org/fis2005/F.04.abstract.pdf

${ }^{17}$ SUNSTEIN, 210

18 See the Wikipedia biography of Theodore Kaczynski, available at: http://en.wikipedia.org/wiki/Theodore_Kaczynski.

${ }^{19}$ Morris Cohen, The Basis of Contract, 46 HaRvard Law ReVIEW 553 (1933) 
paid to employers would be acceptable. I am not advocating regulation requiring cross-links, since it would clearly be unconstitutional as well as unenforceable in a practical sense, and have a chilling effect on the discussion of controversial topics. However, I do think that Sunstein's change of opinion on the topic leaves the freedom of speech chapter in his new book strangely out of balance and incomplete.

Although Sunstein may be disinclined to fully present opposing points of view, and not completely up-to-speed on all of the latest uses of the Internet to improve democracy, one cannot accuse him of being a Luddite. According to the Nobel Laureate Ronald Coase, eliminating transaction costs causes firms to become smaller ${ }^{20}$, and individuals to become more autonomous vis-à-vis the state due to their ability to bargain for the most efficient use of resources regardless of their initial allocation without the need for state regulation. ${ }^{21}$ Under a Coasian analysis of Sunstein's theory, the Internet's minimizing of transaction costs associated with economic activity would contribute to social fragmentation by giving primacy to the individual over the state and large corporations. This does not cause Sunstein to embrace the regressive suggestion that transaction costs should be maintained at artificially high levels, since he is of the view that the Coase theorem on transaction costs is not borne out in practice, mainly due to the endowment effect ${ }^{22}$. Moreover, in his book, Infotopia, which was published in 2006, Sunstein is very sanguine about the prospects of technologically mediated solutions to the problems of deliberative democracy, especially prediction markets. In Infotopia, he extensively refers to Friedrich Hayek's notion of the market as an efficient information aggregator. ${ }^{23}$ In this regard, Sunstein is part of a growing group of liberal academics who increasingly have been adopting the ideas

${ }^{20}$ Ronald H. Coase, The Theory of the Firm, 4 ECONOMICA 386 (1937)

${ }^{21}$ Ronald H. Coase, The Problem of Social Cost, 3 JOURNAL OF LAW AND ECONOMICs 1 (1960)

${ }^{22}$ Christine Jolls, Cass R. Sunstein and Richard H. Thaler, A Behavioral Approach to Law and Economics, in BEHAVIORAL LAW \& ECONOMICS, 13, 18 (Cass R. Sunstein, ed., 2000)

${ }^{23}$ Sunstein, Infotopia - How Many Minds Produce KnOwledge, 14, 118, 140, 156, 186, 221 (2006) 
of scholars such as Hayek, who borders on the libertarian school. ${ }^{24}$ The anemic, incomplete and somewhat contrite ${ }^{25}$ analysis in Republic.com 2.0, which was published in the year after Infotopia, is therefore perhaps explainable as Sunstein signaling that he is finally giving up the notion of encouraging meaningful deliberation in small to medium-sized groups in a Habermasian $^{26}$ way, and is instead focusing on using technology to aggregate the dispersed information of non-deliberating large groups.

Another general concern I have with Republic.com 2.0 is that it perpetuates the overly US-centric approach that permeated the original book. In the 6 years since 2001, when the original book was published, Internet use has grown much more slowly in North America than it has in the rest of the world. According to the statistics from the International Telecommunications Union, the number of Internet users in North America during the period 2000 - 2007 has increased by $119.4 \%$, whereas in the rest of the world, the increase as a whole was $302.7 \% .{ }^{27}$ This increase is not solely attributable to the growth of developing countries. In Europe, the increase in Internet users during that period was 221.5\%, almost double the rate of increase in North America ${ }^{28}$. These statistics reveal that when Sunstein's original book was published in 2001, the US contained about one-third of all Internet users world-wide, but in 2007 when Republic.com 2.0 was published, the US contained less than one-

\footnotetext{
${ }^{24}$ E.g. Yochai BenKLeR, The WeAlth of Networks (2006) [reviewed by James Brink in 7 GERMAN L. J. 853 (2006), available at: http://papers.ssrn.com/sol3/papers.cfm?abstract_id=967505]; Tim Wu, Intellectual Property, Innovation and Decentralized Decisions, 92 VIRginia LAW REVIEW 101 (2006).

${ }^{25}$ This contrition was foreshadowed to some degree in the 2002 edition of Republic.com, which contained a new section entitled "Afterword" where Sunstein made some effort to characterize himself as not anti-Internet, although he did not withdraw any of his key original policy proposals.

${ }^{26}$ JÜRGEN HABERMAS, BETWEEN FACTS AND NORMS: CONTRIBUTIONS TO A DisCOURSE THEORY OF LAW AND DEMOCRACY, 940 (1991)

27 Internet World Stats - North America Internet Users and Population Statistics, available at: http://www.internetworldstats.com/stats14.htm.
}

28 Internet World Stats - Internet Usage in Europe, available at: http://www.internetworldstats.com/stats4.htm. 
fifth of Internet users across the globe. It would seem, then, that Sunstein would have wanted to seize the opportunity in his new book to broaden the scope of his analysis beyond the US. However, Sunstein has generally failed to do this.

The only substantive reference in Republic.com 2.0 to non-US laws is in his chapter on freedom of speech, where he argues for using a conception of the First Amendment's provisions on the subject as being rooted in the need to foster democratic deliberation. He states, "Indeed, in many democracies - including, for example, Germany and Italy - it is well understood that the mass media can be regulated in the interest of improving democratic self-government."29 This sentence also appears in the original 2001 version of Republic.com. In both versions, the passage is supported by a reference to some material in his 1993 book, Democracy and the Problem of Free Speech ${ }^{30}$ which, of course, does not mention the Internet since it was nascent at the time. This material points out that Article 5(1) of the German Constitution guarantees everyone the right "to express and disseminate his opinion by speech, writing and pictures" and "to inform himself from generally accessible sources." Sunstein notes that the German Constitutional Court concluded that this provision of the Constitution means that broadcasting institutions are required to give an outlet for diverse opinions. He also notes that the German Court explicitly refused to tie this ruling to the scarcity of spectrum issue. ${ }^{31}$ Although Sunstein, in Republic.com 2.0, does not use this line of argument to advocate for regulation requiring links between web sites of opposing viewpoints, as he did in the original version, he does use it to support his general view that efforts should be made for bloggers and web site owners to adopt codes of practice whereby they agree to link to sites with opposing viewpoints. It seems to be somewhat unfortunate that Sunstein has not managed to update his almost 15 year old material concerning European law. It is significant that Germany, for example, has not extended its broadcast fairness doctrine to web sites and boggers. Also, in 2007, the European Parliament passed new provisions covering broadcast-

\footnotetext{
${ }^{29}$ SunSTEIN, 178.

${ }^{30} I d ., 238$, n. 13.

${ }^{31}$ Sunstein, Democracy AND the Problem of Free SPEeCH, 77 - 81 (1993)
} 
like media (streaming video) on the Internet, ${ }^{32}$ but not extending the fairness or right of reply doctrines to bloggers and web-sites generally. Omitting this important EU development (which has been ongoing since at least 2005) not only shows Sunstein's excessive US-centricity, but results in the reader possibly being left with the mistaken impression that, in Europe, constitutions such as the one of Germany may lead to a different outcome on the mandatory cross-links issue than in the US, which is not the case.

A further result of Sunstein's narrow, US-centric approach is to ignore the issue of English's role as the effective lingua franca of the Internet. The original primacy of English was due to path dependency arising from several factors, e.g. the Internet's predecessor, the ARPANET, arose in the US in the 1960's, and early computers did not have the linguistic capability to properly represent non-English characters. Although approximately only one-third of Internet users are native English language speakers, ${ }^{33}$ it is estimated that the total proportion of English language content on the Internet is as high as two-thirds ${ }^{34}$, meaning that English is the default language for persons accessing content in their non-native language. It is perhaps somewhat ironic that, in his US-centricity, Sunstein has missed a counter-argument that a form of global "social glue" exists in the lingua franca that stems from the Internet's US heritage.

Finally, it is surprising that Republic.com 2.0 completely lacks references of any sort to the growing phenomenon of virtual worlds, such as World of Warcraft and Second Life. Virtual worlds are online, immersive, persistent, three-dimensional environments which individuals can participate in through a representation of themselves known as an avatar.

32 Directive 2007/65/EC of the European Parliament and of the Council of 11 December 2007 amending Council Directive 89/552/EEC on the coordination of certain provisions laid down by law, regulation or administrative action in Member States concerning the pursuit of television broadcasting activities, available at: http://www.europarl.europa.eu/oeil/FindByProcnum.do?lang=2\&procnum=COD /2005/0260.

33 Internet World Stats - Top Ten Languages Used in the Web, available at: http://www.internetworldstats.com/stats7.htm.

${ }^{34}$ English in Computer available $\quad$ Science, http://en.wikipedia.org/wiki/English_on_the_Internet \#English_on_the_Internet. 
World of Warcraft and Second Life, which are probably the best known virtual worlds today arose after Sunstein's original Republic.com was published in 2001. Although there were some well-known virtual worlds, such as EverQuest and Ultima Online, that existed since the late 1990's, and Sunstein's lack of mentioning them in the original book is perhaps excusable given their relative newness, his failure to mention virtual worlds in the 2007 Republic.com 2.0 is surprising. World of Warcraft currently has approximately 8 million active subscribers worldwide, and Second Life has received prominent press coverage in most major media outlets, including a recent article in The Economist ${ }^{35}$. Second Life (SL) contains virtual presences of many large corporations, such as Cisco, IBM, Reuters, and General Motors. In addition, several universities use SL for teaching classes, including Harvard and New York Law School. Sweden actually maintains a virtual embassy inside SL. Edward Castronova, the pioneering virtual world scholar and economist from Indiana University estimates that a conservative estimate of the total number of virtual world users in 2008 would be approximately 30 million. ${ }^{36}$ Although this is still small compared to the number of Internet users worldwide, it is growing at an exponential rate. For example, World of Warcraft, which started in 2004, had about 1 million subscribers in its first year and a little over three years later has increased its subscribers to about 8 million. At this rate (doubling every year or so), the current total number of virtual world users could reach 1 billion in five years and be in the general range of the total number of Internet users. Moreover, the coming third iteration of the Internet, Web $3.0^{37}$, expected in the next 5 to 10 years, could involve the conversion of the entire Internet into one virtual world, or an interconnected series of them.

What relevance then would these virtual worlds have for Sunstein's arguments? Virtual worlds tend to create a shared experience, (social glue), on a massive scale, often across national boundaries. As Castronova notes in his provocative new book, Exodus to the Virtual World,

35 Getting Serious, Technology Quarterly, Economist.com (6 December 2007), available at: http://www.economist.com/opinion/displaystory.cfm?story_id=10202591

${ }^{36}$ EdWARd CASTRONOVA, EXodus TO THE VirTual WorLd, 6 (2007)

${ }^{37}$ The current stage, known as Web 2.0, arose with the relatively recent emergence of "grass roots" features such as wikis, blogs, YouTube and Facebook. 
technology has given us both empowerment and independence, but at the cost of a sense of community. Virtual worlds have the potential to restore this sense of shared values and beliefs, through the use of shared myths. Castronova cites the work of Tolkien and Carl Jung as positing the value of shared mythical entities in interpreting and crafting the real world. Castronova goes even farther and argues that virtual worlds will actually begin to have an effect on our expectations of the real world, and will lead to policy proposals for a new real world social order that would minimize extremism, marginalization and fragmentation. These proposals would include full employment based on piece work, organizations based on flexible ad hoc work teams rather than hierarchies, a shared myth or a common religion, and a zero-growth (in macro-economic terms) focus on enjoyment or fun rather than the perpetual increase in wealth, which are all features of current role-playing virtual worlds such as World of Warcraft. I will admit that some of these proposals are rather far-fetched, but even if one does not believe in the feed-back effect of virtual worlds into the real one in this regard, it is clear that virtual worlds do provide a potential form of social glue and shared experiences on a massive scale that would obviate any pressing need for Sunstein's cross-links codes of practice, subsidized deliberative forums, and disclosure regulations. Sunstein might reply that these are just role-playing games, after all, and are not substitutes for earnest electronic town hall meetings, where issues important to deliberative democracy are discussed. However, despite the fact that these worlds will inevitably be owned by corporations, rather than the state, there may be rights of free speech in such worlds, based on the notion of the company town principle, which would make it easier for persons to be exposed to a wide range of issues and not merely hide from reality in a fantasy world. ${ }^{38}$

Both the original Republic.com and the arguably misnamed Republic.com 2.0 commence with a discussion of "The Daily Me" which was a term coined in 1995 by Nicholas Negroponte of MIT to describe a futuristic communications environment in which you could personally design in advance a customized source of information through filtering technologies. The Daily Me would ensure that you did not receive any

${ }^{38}$ Peter S. Jenkins, The Virtual World as a Company Town - Freedom of Speech in Massively Multiple Online Role-Playing Games, 8 JOURNAL OF INTERNET LAW 1 (2004), available at: http://papers.ssrn.com/sol3/papers.cfm?abstract_id=565181 
unwanted information, and only were exposed to topics, viewpoints, or styles that you chose in advance, eliminating unexpected and unwanted encounters. Some of the criticism of Sunstein's 2001 book was based on the fact that perfect filtering would likely never be achieved in the foreseeable future. ${ }^{39}$ At the end of 2007, such filtering has still not been achieved. If and when it does become a reality, as Castronova states, the technology may have advanced to the stage where the filtering takes the form of quasi-personalized virtual worlds each of which has, for example, 1,000 live players and 100 million automated characters ("bots"), and the latter's function is to educate, inspire, entertain and even flatter the former according to each live player's idiosyncratic interests. ${ }^{40}$ If there would be several million of these virtual worlds, and each of them is patterned on the identical mythology, landscape, economy and social structure, then it would seem that it is possible on a massive scale to meet both the objective of maintaining common experiences and the goal of providing a customized form of feedback ${ }^{41}$. As Castronova points out, such personalized worlds would provide a forum for the marginalized or frustrated in society to fulfill their fantasies of being successful, (star quarterback in the Super Bowl, General commanding a great army, brilliant architect etc.). This would lessen the appeal of extremist groups that attempt to recruit such disgruntled individuals as terrorists, criminals or gang members and would act as a counter-measure to Sunstein's concerns about technological personalization tending to facilitate extremism. $^{42}$

In conclusion, Sunstein's Republic.com 2.0 is much less than it could have been had the author cited opposing points of view more thoroughly and frequently, not been so US-centric, and taken a broader view of new uses of the Internet to enhance democracy, such as voter mobilization and politician voting record sites, i.e. www.moveon.org and

\footnotetext{
${ }^{39}$ Dan Hunter, Phillipic.com, 90 CALIFORNIA LAW REVIEW, 611 (2002)

${ }^{40}$ Edward Castronova, Exodus to the Virtual WorLd, 180 (2007)

41 The presence of bots in the virtual world may also be necessary to avoid ethical problems. See, Peter S. Jenkins, Historical Simulations - Motivational, Ethical and Legal Issues, 11 JOURNAL OF FUTURES STUDIES 23, (2006), available at: http://papers.ssrn.com/sol3/papers.cfm?abstract_id=929327

${ }^{42}$ CAstronova, (note 40) 181.
} 
http://www.maplight.org/. In addition, the book would have benefited considerably from a discussion of the current state and possible future of virtual worlds. Sunstein should be given credit, however, for withdrawing the misguided policy proposal presented in the original 2001 Republic.com for legislation requiring cross-links between web sites of opposing viewpoints. It is indeed fortunate that in the dark, confused and vulnerable period immediately after $9 / 11$, no politicians chose to act on that proposal. 